\title{
1. INTRODUCTION, CRUISE SUMMARY, AND EXPLANATORY NOTES: DEEP SEA DRILLING PROJECT LEG 86, WESTERN NORTH PACIFIC ${ }^{1}$
}

\author{
Audrey A. Wright, Deep Sea Drilling Project, Scripps Institution of Oceanography²
}

\section{INTRODUCTION AND OBJECTIVES}

One of the long-standing goals of the Deep Sea Drilling Project (DSDP) has been to study the oceanic paleoenvironment of the western Pacific through deep sea drilling. Two complementary legs were planned to address this problem: Leg 86 in the western North Pacific and Leg 90 along the Lord Howe Rise in the western South Pacific (Kennett, von der Borch, et al., in press).

The primary objective of Leg 86 was to drill a northsouth transect of four sites across the Kuroshio Current system, from subtropical to subarctic waters (Staff Scientific Party, 1982). The late Neogene sections recovered at these sites would help to unravel the preglacial and Quaternary paleoceanographic history of the Kuroshio Current system and to determine whether the Miocene onset of biosiliceous sedimentation in the region was synchronous or diachronous. Hydraulic piston coring (HPC) of two holes at each site was planned to allow a high-resolution late Neogene midlatitude stratigraphy using paleomagnetics, tephrachronology, stable isotopes (when possible), and biostratigraphy.

Secondary objectives of Leg 86 included the following: First, to hydraulic piston core the Cretaceous/Tertiary boundary at the Shatsky Rise for midlatitude calcareous biostratigraphic, paleomagnetic, and geochemical studies. The late Neogene carbon and oxygen isotope record determined at this site would be compared with the noncalcareous (siliceous) sites drilled to the north. Second, to recover a "type" North Pacific red clay section for geochemical, paleomagnetic, and geotechnical studies. The low biogenic and terrigenous yield at this site would allow assessment of the nature and history of authigenic and eolian sedimentation during the Late Cretaceous and Cenozoic. The nature of the red clay/chert boundary could also be assessed, particularly in terms of enhanced diagenesis of the basal clay. Third, to determine the thickness and character of sediments at the site of the proposed Defense Advanced Research Projects Agency (DARPA) downhole seismometer experiment (Leg 88) to allow design of casing strings. A fourth objective, that of recovering a late Quaternary section of the Japanese continental margin to study water-mass boundary migration, was not met because of time constraints.

\footnotetext{
${ }^{1}$ Heath, G. R., Burckle, L. H., et al., Init. Repts. DSDP, 86: Washington (U.S. Govt. Printing Office).

2 Address: Ocean Drilling Program, 500 University Drive West, Texas A\&M University. College Station, Texas 77843 .
}

\section{SUMMARY OF RESULTS}

Eleven holes at six sites, Sites 576 through 581, were occupied during Leg 86 (Table 1). Locations of these six sites are shown in Figure 1 and generalized lithologic sections are shown in Figure 2.

Site 576 , located beneath the central water mass east of Shatsky Rise in $6,217 \mathrm{~m}$ water depth (Fig. 1), recovered a "type" red clay section in each of three HPC holes. One complete section was stored vertically, unopened, for shore-based geotechnical studies (Marine Geotechnical Consortium, this volume). Fifty-five meters of Pleistocene to Cretaceous pelagic clay overlies about $20 \mathrm{~m}$ of interbedded Cretaceous carbonate turbidites and pelagic clay overlying chert (Fig. 2). The upper 20 to $30 \mathrm{~m}$ of the pelagic clay is yellowish brown, silty, and slightly biosiliceous. Underlying that, down to the interbedded turbidites and clay, is a classic dark brown "red clay" section. By analogy with North Pacific clay sections farther east, we infer that the upper part of the section is dominated by eolian debris from Asia, the flux of which increased from the late Miocene or early Pliocene as the site moved farther into the influence of the westerlies and as an increase in global aridity associated with the onset of Northern Hemisphere glaciation made large amounts of material available for wind transport (Janecek, this volume; Leinen, this volume). The underlying clays include a large authigenic component; they accumulated at $4 \mathrm{~m} / \mathrm{m}$.y. or less.

Site 577 is located on the west side of Shatsky Rise close to Site 47 in $2678 \mathrm{~m}$ of water (Fig. 1). An unusually good late Cenozoic sequence, a Paleogene sequence, and an undisturbed record of the Cretaceous/Tertiary boundary were recovered at this site. The sediments recovered are all nannofossil oozes ranging from white to light gray to pale brown in color and from late Pleistocene to latest Maestrichtian in age (Fig. 2). The percentage of radiolarians and diatoms decreases downcore. A major unconformity separates late Miocene from middle Eocene sediments at approximately $61 \mathrm{~m}$ below the seafloor. This unconformity was previously reported at Site 47 (Heezen et al., 1971) and was expected. Foraminifers and nannofossils indicate two minor hiatuses, one in the middle Eocene and the other in the middle Paleocene. Both physical properties and heat flow measurements seem to "sense" the late Miocene/middle Eocene unconformity. There is a sudden increase in bulk density (and decrease in water content) just below the unconformity, as well as a rapid increase in compressional wave velocity ( 1.48 to $1.53 \mathrm{~km} / \mathrm{s}$; Schultheiss, this vol- 
Table 1. DSDP Leg 86 drill sites.

\begin{tabular}{|c|c|c|c|c|c|c|c|c|c|}
\hline Hole & Dates (1982) & Latitude (N) & Longitude (E) & $\begin{array}{c}\text { Water } \\
\text { depth (m) }\end{array}$ & $\begin{array}{l}\text { Penetration } \\
\text { (m) }\end{array}$ & $\begin{array}{l}\text { No. of } \\
\text { cores }\end{array}$ & $\begin{array}{l}\text { Length } \\
\text { cored }(\mathrm{m})\end{array}$ & $\begin{array}{l}\text { Length } \\
\text { recovered (m) }\end{array}$ & $\begin{array}{c}\text { Average } \\
\text { recovery (\%) }\end{array}$ \\
\hline 576 & 16-18 May & $32^{\circ} 21.36^{\prime}$ & $164^{\circ} 16.54^{\prime}$ & 6217 & 69.2 & 8 & 69.2 & 68.52 & 99 \\
\hline $576 \mathrm{~A}$ & 18-19 May & $32^{\circ} 21.38^{\prime}$ & $164^{\circ} 16.52^{\prime}$ & 6217 & 65.7 & 7 & 65.7 & 66.20 & 101 \\
\hline $576 \mathrm{~B}$ & 19-20 May & $32^{\circ} 21.37^{\prime}$ & $164^{\circ} 16.52^{\prime}$ & 6217 & 74.8 & 9 & 74.8 & 74.07 & 99 \\
\hline 577 & 23 May & $32^{\circ} 26.51^{\prime}$ & $157^{\circ} 43.40^{\prime}$ & 2675 & 118.8 & 13 & 118.8 & 111.07 & 93 \\
\hline $577 \mathrm{~A}$ & 24 May & $32^{\circ} 26.53^{\prime}$ & $157^{\circ} 43.39^{\prime}$ & 2675 & 123.4 & 13 & 123.4 & 110.64 & 90 \\
\hline $577 \mathrm{~B}$ & 25 May & $32^{\circ} 26.48^{\prime}$ & $157^{\circ} 43.39^{\prime}$ & 2675 & 113.9 & 1 & 9.5 & 9.63 & 101 \\
\hline 578 & 27-30 May & $33^{\circ} 55.56^{\prime}$ & $151^{\circ} 37.74^{\prime}$ & 6010 & 176.8 & 20 & 167.8 & 165.02 & 98 \\
\hline 579 & 1 June & $38^{\circ} 37.68^{\prime}$ & $153^{\circ} 50.17^{\prime}$ & 5736.6 & 17.9 & 2 & 17.9 & 16.90 & 94 \\
\hline $579 \mathrm{~A}$ & 2-4 June & $38^{\circ} 37.61^{\prime}$ & $153^{\circ} 50.28^{\prime}$ & 5736.6 & 149.5 & 15 & 135.5 & 115.87 & 86 \\
\hline 580 & 6-8 June & $41^{\circ} 37.47^{\prime}$ & $153^{\circ} 58.58^{\prime}$ & 5375 & 155.3 & 17 & 155.3 & 140.74 & 91 \\
\hline \multirow[t]{2}{*}{581} & 10-13 June & $43^{\circ} 55.62^{\prime}$ & $159^{\circ} 47.76^{\prime}$ & 5476 & 352.5 & 19 & 172.0 & 77.59 & 45 \\
\hline & & & & & & 124 & 1109.9 & 956.25 & 86 \\
\hline
\end{tabular}

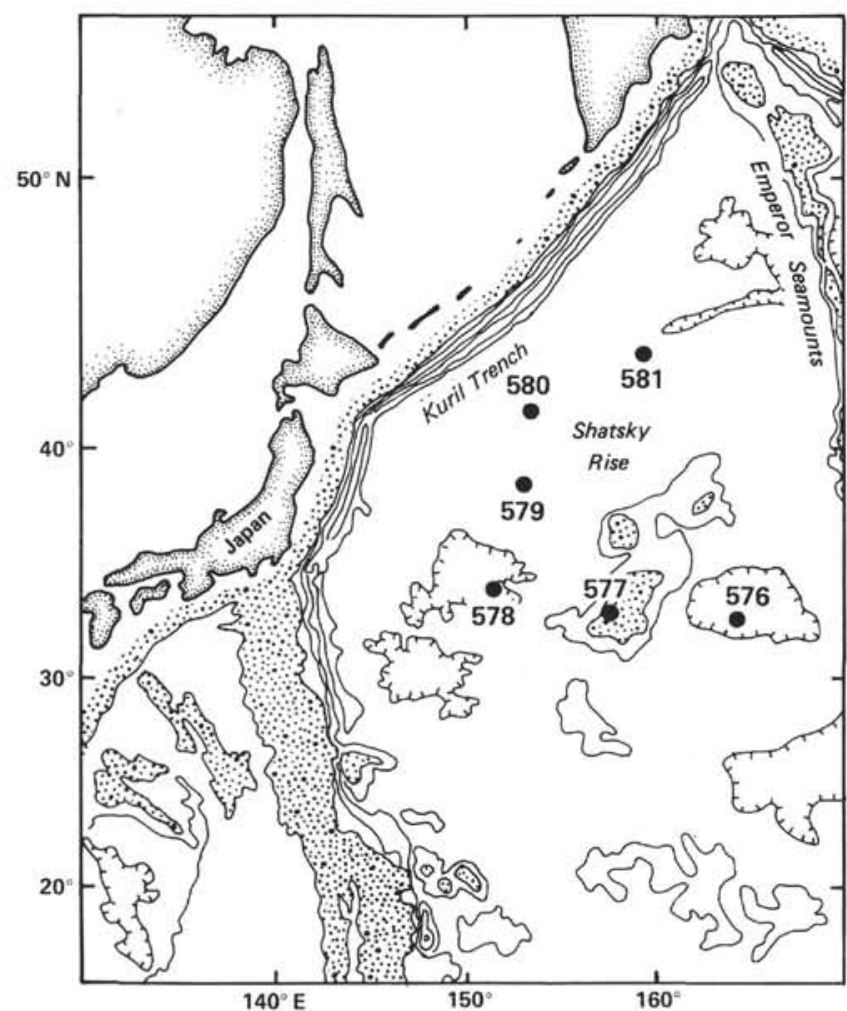

Figure 1. Location map of sites drilled on DSDP Leg 86. Areas shallower than $4 \mathrm{~km}$ stippled, $5-\mathrm{km}$ contour plain, $6-\mathrm{km}$ contour hachured.

ume). The heat flow data show a linear increase with depth until the level of the unconformity, at which point there is an apparent temperature reversal (Horai and von Herzen, this volume). A complete, continuous, and undisturbed Cretaceous/Tertiary boundary sequence was recovered in each of the three holes drilled at Site 577. The boundary is defined by the first appearance of several Tertiary nannofossil taxa (Biscutum romeinii, Thoracosphaera, Cyclagelosphaera) (Monechi, this volume; Monechi et al., this volume). It is located at a sub-bottom depth of about $109.6 \mathrm{~m}$ (Samples $577-12-5,130 \mathrm{~cm}$, $577 \mathrm{~A}-12-4,72 \mathrm{~cm}$, and 577B-1-4, $72 \mathrm{~cm}$ ). Small primitive globigerinid foraminifers appear about $40 \mathrm{~cm}$ below the boundary, unlike the section at Gubbio, where they first appear at the boundary (Heath, Burckle, et al., 1982).

Sites 578 through 581 were drilled as a transect of four sites from $34^{\circ} \mathrm{N}$ to $44^{\circ} \mathrm{N}$ centered about $155^{\circ} \mathrm{E}$, primarily to investigate the paleoceanography of the northwest Pacific. Site 578, the southernmost (most subtropical) site of the transect, is located on the west side of Shatsky Rise in $6,010 \mathrm{~m}$ of water (Fig. 1). A complete section from Pleistocene to Late Cretaceous (Maestrichtian-Campanian) overlying a basal chert was recovered (Fig. 2). The uppermost part of the sediment section consists of $125 \mathrm{~m}$ of biosiliceous clay and radiolariandiatom ooze with abundant ash layers. The upper $76 \mathrm{~m}$ of these biosiliceous clays are suboxic to anoxic (gray and olive gray in color) with many pyrite-cemented layers; from 76 to $125 \mathrm{~m}$ the clays are oxidized (yellow brown and brown in color) with rare ferromanganese nodules. From 125 to $176 \mathrm{~m}$, underlying the biosiliceous unit and overlying the chert, the section is entirely "slick" dark brown to very dark brown, very homogenous pelagic clay that includes a substantial authigenic component. Sedimentation rates drop from almost $40 \mathrm{~m} / \mathrm{m}$.y. at the surface to about $8 \mathrm{~m} / \mathrm{m}$.y. at the base of the biosiliceous section; the pelagic clays accumulated at an average rate of $0.8 \mathrm{~m} / \mathrm{m}$.y., if deposition was continuous. This pelagic clay section complements those recovered at Site 576 and LL44-GPC 3 and provides the basis for preparing an east-west profile of Paleogene authigenic sedimentation (Janecek, this volume).

Site 579 lies near the southern margin of the transition zone between the subtropical and subarctic gyres (Fig. 1). It forms an important link between the more siliceous subarctic sites to the north and the calcareous/ siliceous subtropical sites to the south, and it should therefore record the most extreme southerly excursions of the subarctic front. Site 580 lies near the present-day subarctic front $\left(42^{\circ} \mathrm{N}\right)$ and the northern margin of the transition zone between the subarctic and subtropical gyres (Fig. 1). It therefore serves as the reference point for the modern subarctic/subtropical gyre boundary and should provide a Plio-Pleistocene record of fluctuations in the position of the front. Similar sections of gray and gray green biosiliceous clay and ooze with abundant ash 
layers were recovered at both Sites 579 and 580 (Fig. 2). Site 579 bottomed in biosiliceous clay of early Pliocene age; Site 580 bottomed in biosiliceous clay of late Pliocene age. Although neither site penetrated the base of the siliceous section, the oldest sediments at Site 579 predate the green to yellow brown biosiliceous clay transition at Site 578, so at least that boundary is diachronous along the transect.

Site 581 was drilled both as the northernmost site of the Leg 86 paleoceanographic transect and as a pilot hole for the DARPA downhole seismometer experiment to be carried out on Leg 88 (Fig. 1). Because of time constraints, HPC sampling of the softer sediments at Site 581 was deferred until Leg 88 (and was dropped from the Leg 88 itinerary by them; see Duennebier, Stephen, et al., in press). Hole 581 was rotary cored from $181.5 \mathrm{~m}$ sub-bottom into basaltic basement rocks (Fig. 2). From 181.5 to $223.6 \mathrm{~m}$, the section is reduced (gray and green) late Miocene to earliest Pliocene biosiliceous clay to ooze, similar to but less ashy and pyritic than the sections at Sites 579 and 580. Presumably, the uncored section above is similar, but with more ash and pyritic layers toward the surface. From 223.6 to $244.8 \mathrm{~m}$, the sediment is oxidized (yellow brown) latest middle Miocene to late Miocene biosiliceous clay, which accumulated at about one-sixth the rate of the overlying sediments. The biosiliceous clay is underlaid by "slick," fine-grained, brown to dark brown pelagic clay of presumed middle Miocene age from 244.8 to $276.5 \mathrm{~m}$. From 276.5 to 344 $\mathrm{m}$, we recovered only chert and porcellanite fragments, although the drilling rate suggests that most of the section is soft sediment (clay?). The chert ranges from offwhite to bright reds and yellows and dark brown in color; most of it looks like silicified dark brown pelagic clay. Diatoms from a small vug in a chert fragment at about $287 \mathrm{~m}$ are middle Miocene in age. Medium-gray aphyric basalt was sampled from 344 to $352.5 \mathrm{~m}$. Most fragments have prominent alteration rinds and fractures that are filled with iron oxides and calcite. There is a small amount of fresh-looking glass. If it is primary oceanic crust, it should be about $115 \mathrm{~m}$.y. old (between Mesozoic magnetic Anomalies M-3 and M-4). Additional basalts were drilled at Site 581 during Leg 88 (Holes 581A, 581B, and 581C) and are described in the Leg 88 Initial Reports volume (see Duennebier, Stephen, et al., in press).

By comparing drilling results from Sites 578 and 581 , it is clear that the base of the reduced sediments (at 77 m, 2.75 m.y. old at Site 578 and at $224 \mathrm{~m}, 6.5 \mathrm{~m}$.y. old at Site 580), as well as the base of the underlying yellow brown biosiliceous clay (at $125 \mathrm{~m}, 8 \mathrm{~m}$.y. old at Site 578 and at $245 \mathrm{~m}, 12 \mathrm{~m}$.y. old at Site 581 ) is markedly diachronous from south to north.

A successful first on Leg 86 was the test of the miniature microprocessor-based heat flow unit, designed at Woods Hole Oceanographic Institution (WHOI), that fits into the wall of the core nose of the hydraulic piston corer. It records a temperature with each core at virtually no cost in time. Temperature data were collected at all sites except Site 581; the results are given in Horai and von Herzen (this volume).

\section{EXPLANATORY NOTES}

These explanatory notes are intended to aid the reader in understanding the Leg 86 site chapters that follow. Although procedures followed by the Leg 86 shipboard party were by and large standard DSDP procedures, every DSDP cruise has procedural peculiarities that result from the personalities and scientific priorities involved. This section outlines standard DSDP shipboard procedures and details the Leg 86 deviations from those procedures.

\section{Responsibility of Authorship}

Site summary chapters are coauthored by the entire shipboard scientific party; ultimate responsibility lies with the two co-chief scientists. These chapters are organized into the following sections, with authors' names in parentheses.

Site Summary and Principal Results (Heath, Burckle) Background and Objectives (Heath, Burckle)

Operations (Storms)

Lithostratigraphy (Jacobi, Janecek, Krissek, Lenotre, Wright)

Seismic Correlations (Jacobi)

Biostratigraphy (D'Agostino, Koizumi, Monechi, Morley)

Paleomagnetics (Bleil)

Sediment Accumulation Rates (Bleil, D'Agostino, Koizumi, Monechi, Morley)

Physical Properties (Schultheiss)

Inorganic Geochemistry (Heath, Pine)

Heat Flow (Horai)

Summary and Conclusions (Heath, Burckle)

The interpretations of individual authors have been retained in the sections for which they are responsible. As a result, differences between interpretations in a particular section and those in the conclusions sometimes occur. In addition, interpretations in the site summary chapters reflect knowledge gleaned only from shipboard and initial postcruise analysis. Results of the more detailed shore-based work presented in the manuscripts in the second portion of this Initial Reports volume may necessitate changing these preliminary site chapter interpretations to some extent.

\section{Survey and Drilling Data}

The survey data used for specific site selections are discussed in each site chapter. En route between sites, continuous observations were made of depth, magnetic field, and sub-bottom structure. Short surveys using a precision echo sounder, seismic profiles, and magnetometer were made on Glomar Challenger before dropping the beacon.

While we were under way, depths were continuously recorded on a Gifft precision graphic recorder. The depths 


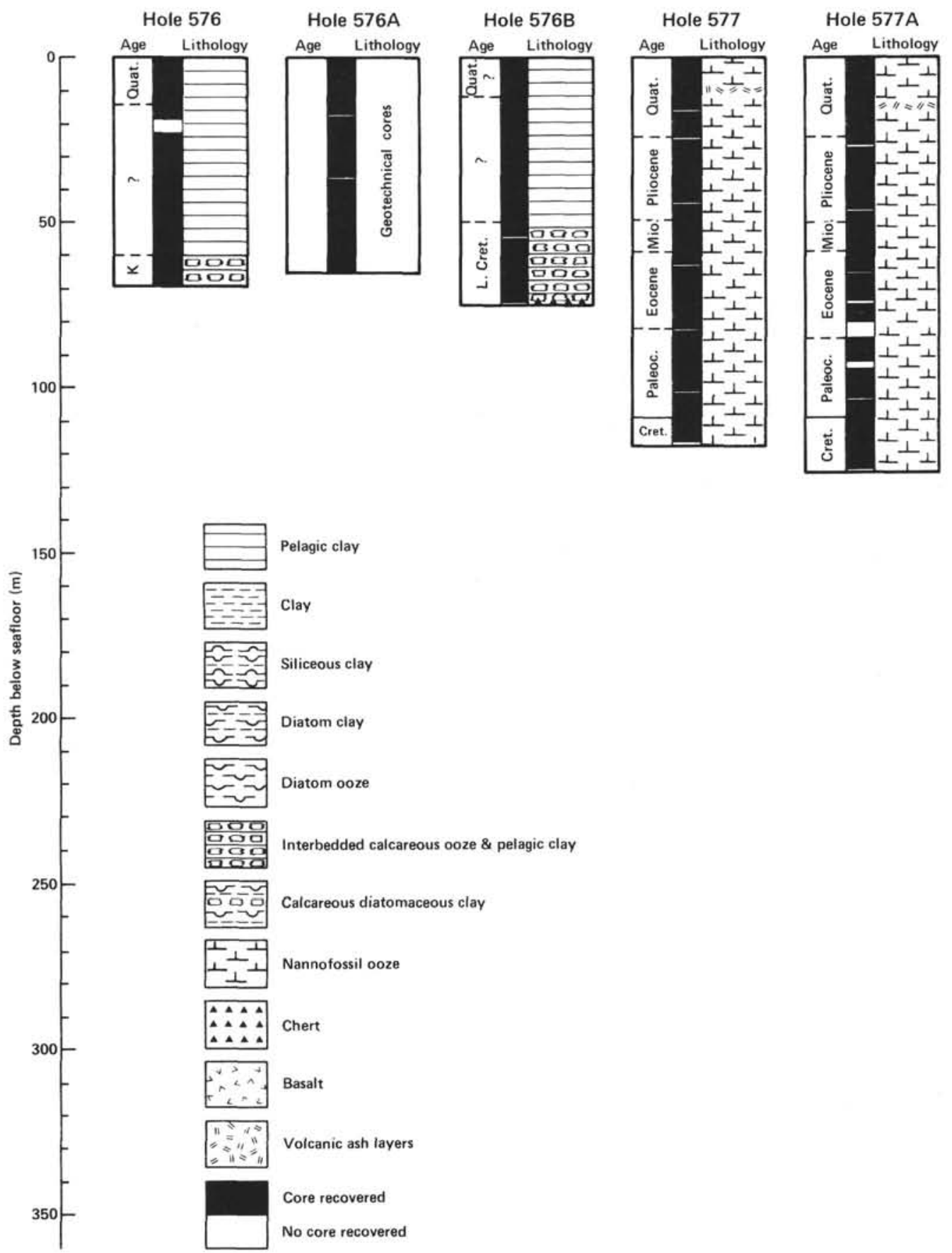

Figure 2. Age, core recovery, and generalized lithologic sections of Leg 86 drill sites.

were read on the basis of an assumed $1463 \mathrm{~m} / \mathrm{s}$ sounding velocity. The water depth (in meters) at each site was corrected (1) according to the tables of Matthews (1939) and $(2)$ for the depth of the hull transducer $(6 \mathrm{~m})$ below sea level. In addition, any depths referring to the drilling platform have been calculated on the assumption that this level is $10 \mathrm{~m}$ above the water line.

The seismic-profiling system consisted of two Bolt air guns, a Scripps-designed hydrophone array, Bolt amplifiers, two band-pass filters, and two Edo recorders, usually recording at two different filter settings.

\section{Drilling Characteristics}

Because water circulation down the hole is open, cuttings are lost on the seabed and cannot be examined. The only available information about sedimentary stratification in uncored or unrecovered intervals, other than from seismic data, is from an examination of the behavior of the drill string as observed on the drill platform. The harder the layer being drilled, the slower and more difficult it usually is to penetrate. There are, however, a number of other variable factors that determine the rate 
INTRODUCTION, CRUISE SUMMARY, AND EXPLANATORY NOTES
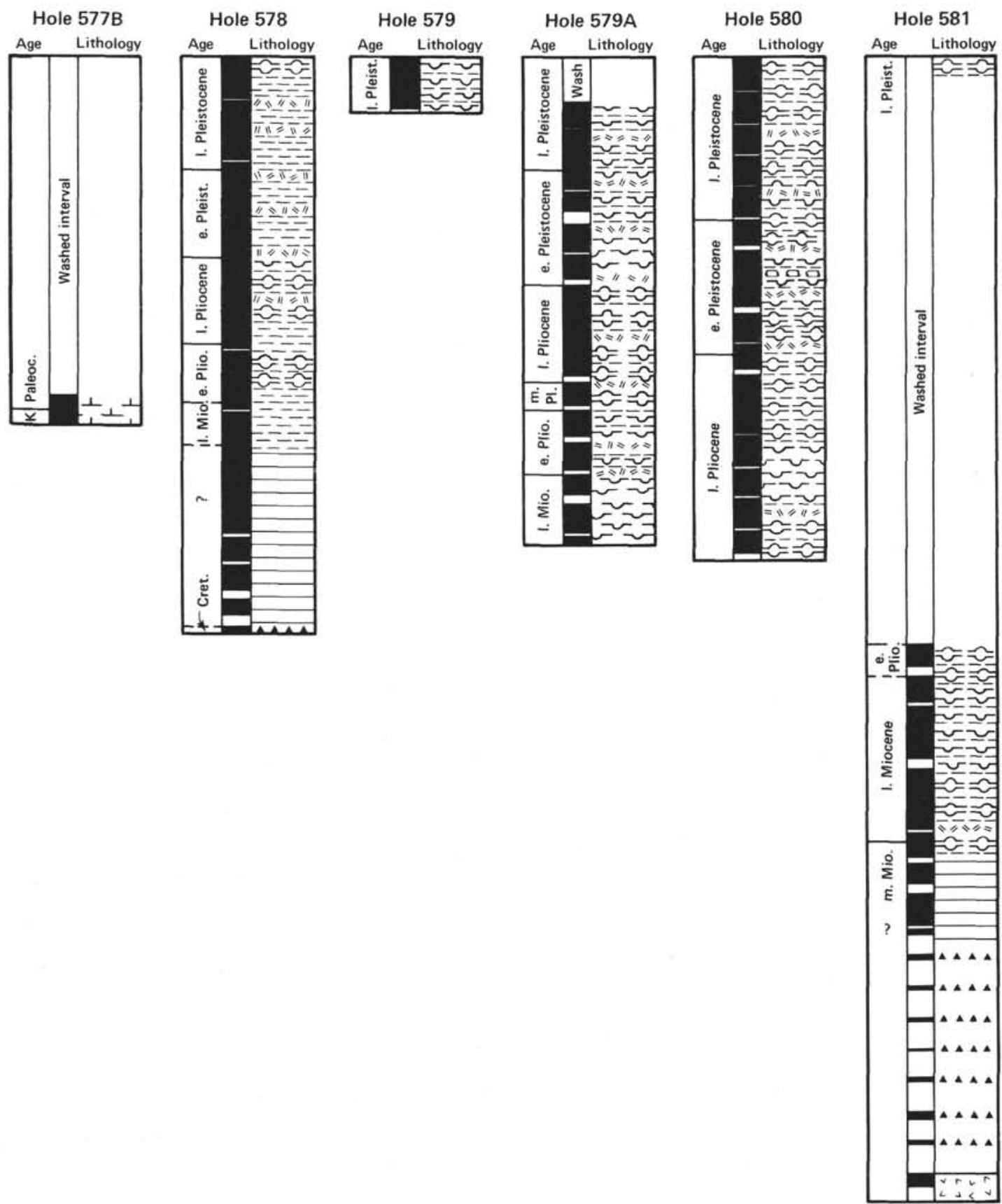

Figure 2. (Continued).

of penetration, so it is not always possible to relate it directly to the hardness of the layers. The parameters of bit weight and revolutions per minute are recorded on the drilling recorder and influence the rate of penetration.

\section{Drilling Deformation}

When cores are split, many show signs of significant sediment disturbance. Such signs include the concavedownward appearance of originally horizontal bands, the haphazard mixing of lumps of different lithologies, and the near-fluid state of some sediments recovered from tens to hundreds of meters below the seabed. It

seems reasonable to suppose that this deformation occurred during or after the cutting of the core. Three different stages during which the core may suffer stresses sufficient to alter its physical characteristics are cutting, retrieval (with accompanying changes in pressure and temperature), and core handling.

\section{Shipboard Scientific Procedures}

\section{Numbering of Sites, Holes, Cores, and Samples}

DSDP drill sites are numbered consecutively from the first site drilled by Glomar Challenger in 1968. Site numbers are slightly different from hole numbers. A site 
number refers to one or more holes drilled while the ship is positioned over a single acoustic beacon. These holes can be within a radius as great as $900 \mathrm{~m}$ from the beacon. Several holes may be drilled at a single site by pulling the drill pipe above the seafloor (out of one hole), moving the ship $100 \mathrm{~m}$ or more from the previous hole, and then drilling another hole.

The first (or only) hole drilled at a site takes the site number. A letter suffix distinguishes each additional hole at the same site. For example: the first hole takes only the site number; the second takes the site number with suffix $A$, the third takes the site number with suffix B, and so forth. It is important, for sampling purposes, to distinguish the holes drilled at a site, because recovered sediments or rocks from cores with the same site number but from different holes usually do not come from equivalent positions in the stratigraphic column.

The cored interval is measured in meters below the seafloor. The depth interval of an individual core is the depth below seafloor that the coring operation began to the depth that the coring operation ended. Each coring interval is generally $9.5 \mathrm{~m}$ long, which is the nominal length of a core barrel. The coring interval may, however, be shorter. "Cored intervals" are not necessarily adjacent to each other, but may be separated by "drilled intervals." In soft sediment, the drill string can be "washed ahead" with the core barrel in place, but not recovering sediment, by pumping water down the pipe at high pressure to wash the sediment out of the way of the bit and up the space between the drill pipe and wall of the hole; however, if thin, hard rock layers are present, it is possible to get "spotty" sampling of these resistant layers within the washed interval, producing a cored interval greater than $9.5 \mathrm{~m}$.

Cores taken from a hole are numbered serially from the top of the hole downward. Full recovery for a single core is normally $9.28 \mathrm{~m}$ of sediment or rock, which is in a plastic liner (6.6 cm I.D.), plus about a $0.2-\mathrm{m}$-long sample (without a plastic liner) in a core catcher. The core catcher is a device at the bottom of the core barrel that prevents the core from sliding out when the barrel is being retrieved from the hole. The sediment core, which is in the plastic liner, is then cut into 1.5 -m-long sections that are numbered serially from the top of the sediment core (Fig. 3). When full recovery is obtained, the sections are numbered from 1 through 7 , the last section being shorter than $1.5 \mathrm{~m}$. The core catcher sample is placed below the last section when the core is described, and labeled "Core Catcher" (CC); it is treated as a separate section (for sediments only).

When recovery is less than $100 \%$, and if the sediment is contiguous, the recovered sediment is placed at the top of the cored interval, and then 1.5-m-long sections are numbered serially, starting with Section 1 at the top. There will be as many sections as needed to accommodate the length of the core recovered (Fig. 3); for example, $3 \mathrm{~m}$ of core sample in a plastic liner will be divided into two 1.5 -m-long sections. Sections are cut starting at the top of the recovered sediment, and the last section may be shorter than the normal 1.5-m length.
When recovery is less than $100 \%$, the original stratigraphic position of the sediment in the cored interval is unknown; we conventionally assign the top of the recovered sediment to the top of the cored interval. This is done for convenience in data handling and for consistency. If recovery is less than $100 \%$ and core fragments are separated, and if shipboard scientists believe that the fragments were not originally contiguous, then sections are numbered serially and the intervening sections are noted as void, whether the fragments as found were contiguous or not.

Samples are designated by distances in centimeters from the top of each section to the top and bottom of the sample interval in that section. A full identification number for a sample consists of the following information (1) Leg, (2) Site, (3) Hole, (4) Core Number, (5) Section, (6) Interval in centimeters. For example, the sample identification number " $86-577 \mathrm{~A}-6-3$, $98-100 \mathrm{~cm}$ " means that a sample was taken between 98 and $100 \mathrm{~cm}$ below the top of Section 3 of Core 6, from the second hole drilled at Site 577 during Leg 86. A sample from the core catcher of this core might be designated "86577A-6,CC (8-9 cm)."

The depth below the seafloor for a sample numbered " $86-577 \mathrm{~A}-6-3,98-100 \mathrm{~cm}$ " is the sum of the depth to the top of the cored interval for Core $6(47.4 \mathrm{~m})$ plus the $3 \mathrm{~m}$ included in Sections 1 and 2 (each $1.5 \mathrm{~m}$ long) plus the $98 \mathrm{~cm}$ below the top of Section 3. The sample in question is therefore located at $51.38 \mathrm{~m}$ sub-bottom, which in principle is the sample sub-seafloor depth (sample requests should refer to a specific interval within a core section, rather than the depth below seafloor). Subseafloor depths for Leg 86 sediments drilled at Site 576 were adjusted by matching paleomagnetic reversals and distinct lithologic changes recovered in Holes 576, 576A, and 576B. Details for computing adjusted sub-seafloor depths for these sediments are given in Heath et al. (this volume); these adjusted depths supercede those given in the "Operations" section of the Site 576 chapter (this volume).

Two types of coring systems were used on the Glomar Challenger during Leg 86: (1) the standard DSDP rotary-coring system, and (2) the hydraulic piston coring (HPC) system. Conventions regarding the cataloguing of the HPC cores are the same as those for the rotary cores. A full HPC core, therefore, consists of six sections, each 1.5-m long, a seventh section of variable length, and a core catcher as much as $0.2 \mathrm{~m}$ long. For details regarding the HPC operation, the core orientation, and the special HPC features, see Prell, Gardner, et al. (1982).

\section{Handling of Cores}

Cores were normally cut into 1.5 -m sections, sealed, and labeled; the sections were then brought into the shipboard core laboratory for processing. Continuous wetbulk density determinations using the Gamma Ray Attenuation Porosity Evaluator (GRAPE) were made before the sections were split. 

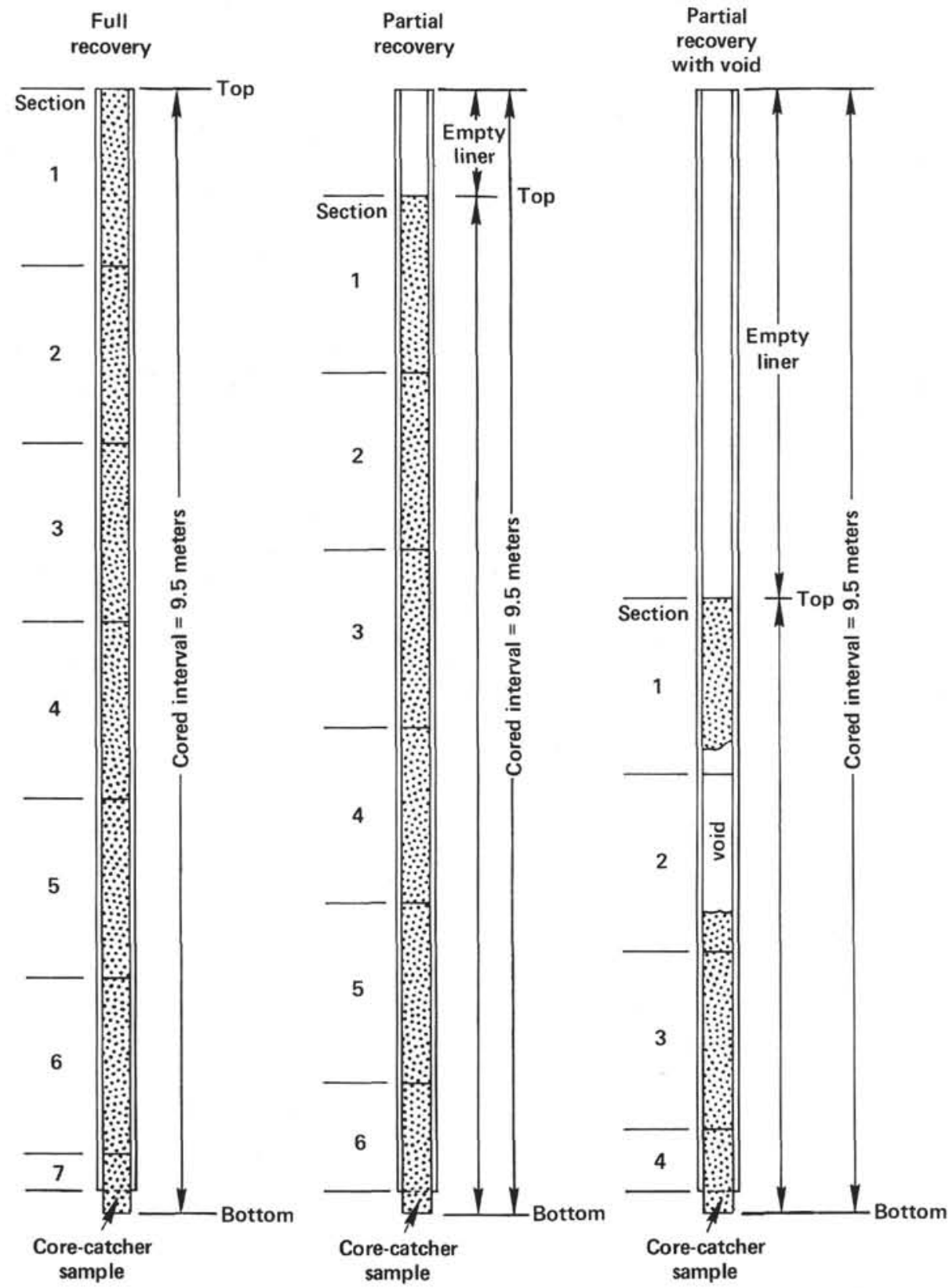

Figure 3. Diagram showing procedure in cutting and labeling of core sections.

The cores were then split longitudinally into "work" and "archive" halves with the wire cutter. All sections from a given HPC core were oriented relative to each other with the result that all archive halves are from the same side of the hole; their orientation relative to the Earth's magnetic north is, however, unknown. Compressional and shear wave velocity, vane shear, and thermal conductivity measurements were made on the split work halves. Samples subsequently extracted from the work half include those for measurement of wet-bulk density by GRAPE and gravimetric techniques (Boyce, 1976), measurement of calcium carbonate percentage with the carbonate bomb (Müller and Gastner, 1971), and geochemical, paleontological, paleomagnetic, geotechnical, sedimentologic, and petrologic studies.
The color, texture, structure, physical disturbance by the drill bit, and composition of the various lithologically different parts of each archive half were described on standard visual core description sheets (one per section). Any unusual features were noted. One or more smear slides were made from the sediments recovered in each core and examined by petrographic microscope. The archive half of the core section was then photographed.

After the cores were sampled and described, both the "work" and "archive" halves were maintained in cold storage aboard Glomar Challenger until they were transferred to the DSDP repository. Whole core sections removed for organic geochemistry studies were frozen immediately on board ship and kept frozen. All Leg 86 
cores are presently stored at the Ocean Drilling Program (ODP) West Coast Repository (Scripps Institution of Oceanography).

Visual core description sheets, smear slide descriptions, and carbonate bomb (percentage $\mathrm{CaCO}_{3}$ ) determinations (all done aboard ship) provide the data for the summary core descriptions or "barrel sheets" presented at the end of the site chapters in this volume (Fig. 4). Locations of smear slide and carbonate bomb samples are shown with a symbol on these barrel sheets.

Cores collected on Leg 86 from Hole 576A were intended for shore-based geotechnical studies and were therefore handled differently. They were cut into $1.5-\mathrm{m}$ sections, sealed, labeled, and GRAPEd, but not split. Instead, they were stored in vertical position in cold storage aboard the Glomar Challenger, shipped to the West Coast Repository, and subsequently sampled by shore-based scientists for detailed geotechnical studies (Marine Geotechnical Consortium, this volume).

\section{Description of Sediments}

\section{Sediments and Sedimentary Rocks Core Description Form}

\section{Drilling Disturbance}

Recovered rocks, particularly soft sediments, may be extremely disturbed. This mechanical disturbance is a result of the coring technique, which uses a $25-\mathrm{cm}$-diameter bit with a 6-cm-diameter opening for the core sample. Symbols for the five disturbance categories used for soft and firm sediment on Leg 86 are shown on the core description form in the column entitled "Drilling Disturbance" (Fig. 4). The disturbance categories are defined as follows: (1) Slightly deformed: bedding contacts are slightly bent. (2) Moderately deformed: bedding contacts have undergone extreme bowing. Firm sediment is fractured. (3) Very deformed: bedding is completely disturbed or homogenized by drilling, sometimes showing symmetrical diapir-like structure. (4) Soupy: water-saturated intervals that have lost all aspects of original bedding. (5) Breccia: indurated sediments broken into angular fragments by the drilling process, perhaps along preexisting fractures.

\section{Sedimentary Structures}

It may be extremely difficult to distinguish between natural structures and structures created by the coring process in sediment cores. Consequently, the description of sedimentary structures was optional. Locations and types of structures appear as graphic symbols in the column entitled "Sedimentary Structures" on the core description form (Fig. 4). Figure 5 gives the key to the symbols used for sedimentary structures recognized in sediments recovered on Leg 86.

\section{Color}

Colors of the core samples were determined with Munsell Soil Color Charts. Colors were determined immediately after the cores were split and still wet.

\section{Lithology}

Recovered lithologies are represented on the core description forms by a single symbol or by a grouping of two or more symbols (Fig. 6) in the column entitled "Graphic Lithologies" (Fig. 4). The symbols in a grouping correspond to end-members of sediment constituents, such as clay or nannofossil ooze. The symbol for the terrigenous constituent appears on the right-hand side of the column, the symbol for the biogenic constituent(s) on the left-hand side of the column. The abundance of any component approximately equals the percentage of the width of the graphic column its symbol occupies. For example the left $20 \%$ of the column may have a nannofossil ooze symbol, whereas the right $80 \%$ may have a clay symbol, indicating sediment composed of $80 \%$ clay and $20 \%$ nannofossils.

Because of the difference in the length-to-width ratio between the actual sediment core and the graphic lithologic column, it is not possible to reproduce structures as they appear in the core; in the graphic representation they are highly flattened and distorted. The same is true for rock fragments or pebbles in the cores.

\section{Shipboard Analyses}

Smear slide compositions and carbonate bomb analyses determined on board are listed below the written core descriptions on the core description forms. The locations of these samples in the core are given in the column entitled "Samples" (Fig. 4). Locations and intervals of organic geochemistry (OG), interstitial water (IW), physical property (PP), and geotechnical consortium (GTP) whole core samples are given in the "Graphic Lithology" column on the core description forms.

\section{Lithologic Classification of Sediments}

The basic classification system used on Leg 86 was devised by the Joint Oceanographic Institutions for Deep Earth Sampling (JOIDES) Sedimentary Petrology and Physical Properties Panel (SP4) and adopted for use by the JOIDES Planning Committee in March, 1974.

This classification is descriptive rather than generic, and categories are based on sediment parameters measured on board ship. Sediment names are those in common usage, defined within the limits of existing definitions. We treat lithologic types not covered in this classification as a separate category termed "special rock types." A brief outline of the conventions and descriptive data used to construct this classification follows.

\section{Conventions and Descriptive Data}

In this classification scheme, composition and texture are the only criteria used to define the type of sediment or sedimentary rock recovered. Composition is more important for describing sediments deposited in the open ocean, while texture becomes significant for hemipelagic and nearshore sediments. These data come principally from visual estimates of component percentages in smear slides, examined using a petrographic microscope. These data are estimates of areal abundance and 
SITE HOLE CORE CORED INTERVAL

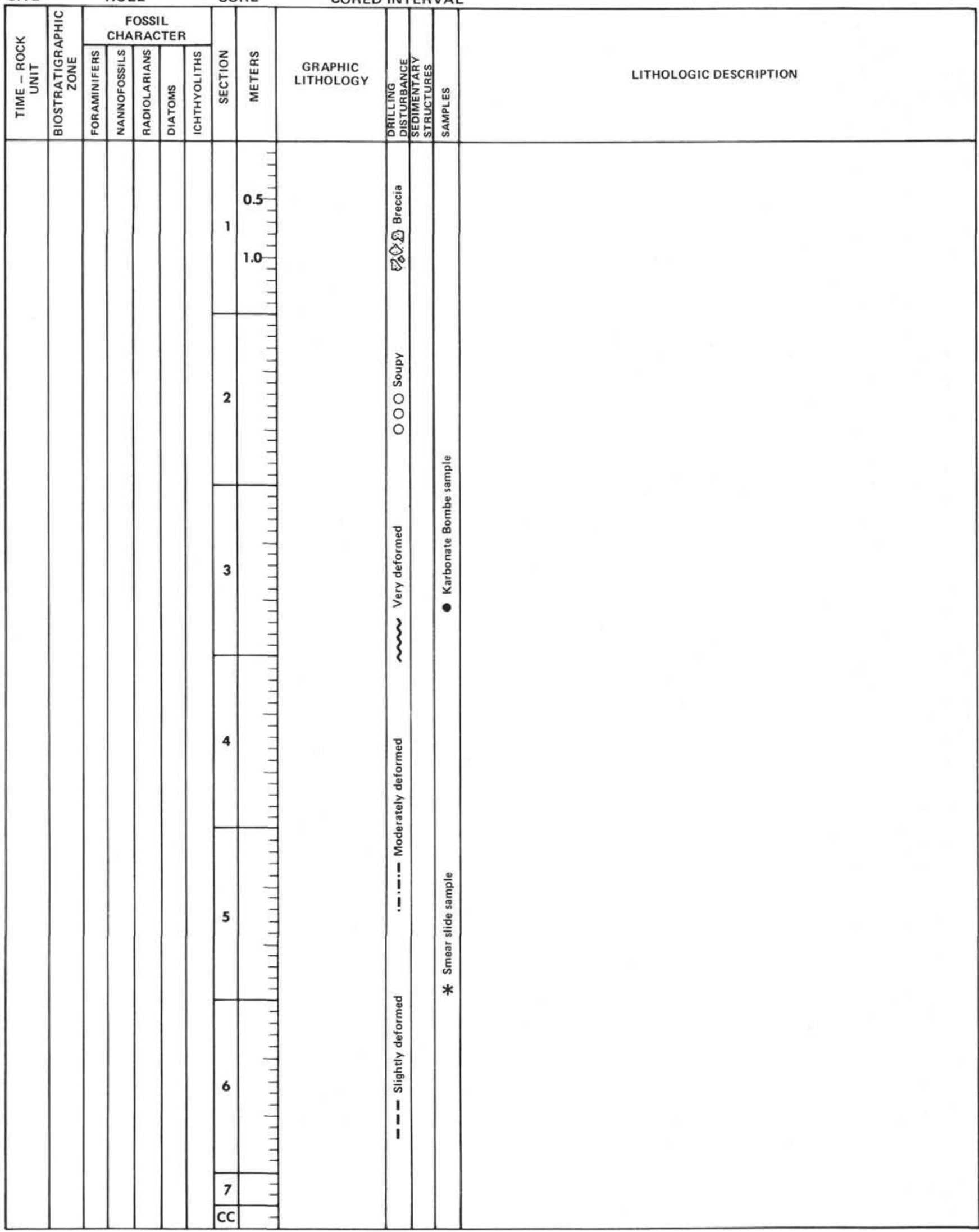

Figure 4. Sample core form for description of sediments and sedimentary rocks ("barrel sheets"). 


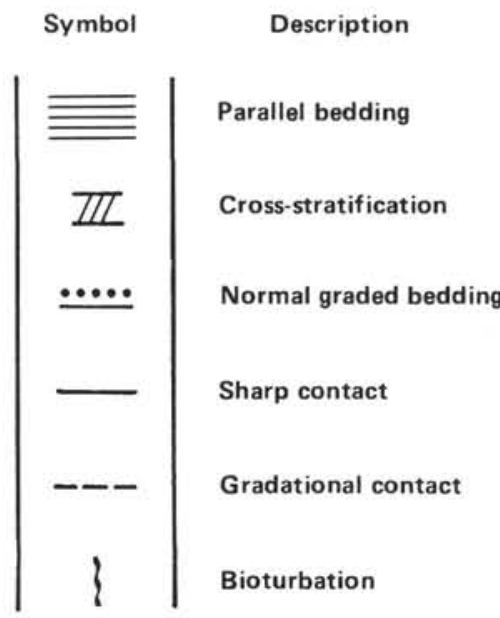

Figure 5. Standard symbols for sedimentary structures recognized in sediments recovered during Leg 86 . These symbols are shown in the "Sedimentary Structure" column of the DSDP core description forms.

size components on the slide and may differ somewhat from more accurate analyses of grain size, carbonate content, and mineralogy. Past experience indicates that quantitative estimates of distinctive minor components are accurate to within 1 to $2 \%$, but that accuracy for major constituents is poorer, $10 \%$. Smear slide data are verified by carbonate content data determined using the carbonate bomb available on board ship.

Where applicable, one or several modifiers are used in naming the type of sediment encountered. In all cases the dominant component appears last in the name; minor components precede, with the least common constituent listed first. Minor constituents occurring in amounts less than $10 \%$ are not included in the name.

The degree of induration or lithification of the recovered sediment is reflected in the sediment name. Calcareous sediments and sedimentary rocks are divided into three categories of induration after Gealy and others (1971). (1) Oozes are soft calcareous sediments with little strength that readily deform under the pressure of a finger or the broad blade of a spatula. (2) Chalks are firm, partially lithified calcareous oozes that are readily scratched with a fingernail or the edge of a spatula. (3) Limestones are hard, well lithified and cemented calcareous sedimentary rocks that are resistant or impossible to scratch with a fingernail or the edge of a spatula. Noncalcareous sediments are called by the sediment name if the material is soft enough for the core to be split with a wire cutter (e.g., silty clay), or by the sediment name plus the suffix stone if the core must be cut with a band saw or diamond saw (e.g., silty claystone).

\section{Types of Sediments, Sedimentary Rocks, and Compositional Boundaries}

\section{Pelagic Clay}

Pelagic clay is principally composed of authigenic pelagic material that accumulated at very slow rates. This
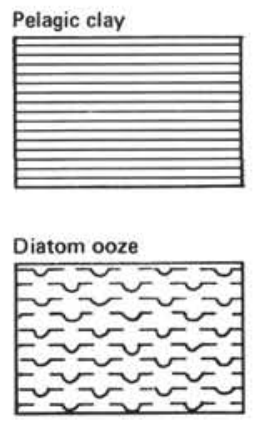

Diatom-rad or siliceous ooze
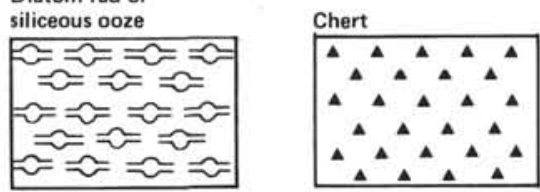

Nannofossil ooze

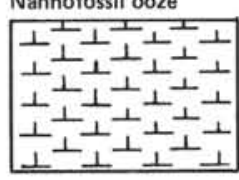

Foraminiferal ooze

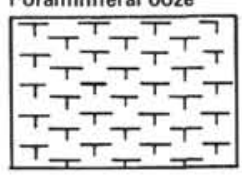

Calcareous ooze

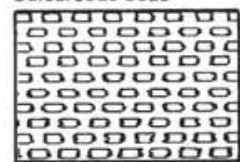

Clay/claystone
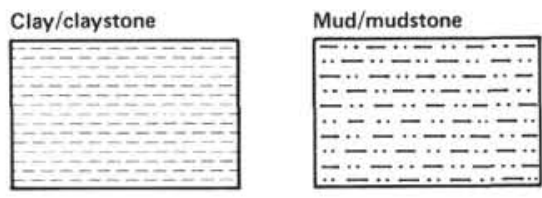

Volcanic ash
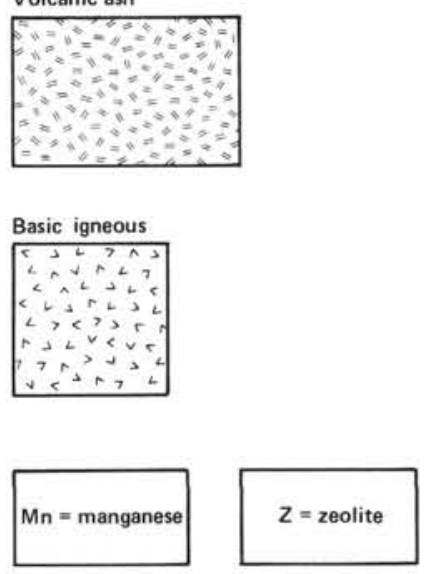

Figure 6. Standard symbols for lithologies drilled during Leg 86 . These symbols are shown in the "Graphic Lithology" column of the DSDP core description forms.

type of sediment has also often been termed "brown clay" or "red clay."

1. Boundary of pelagic clay with terrigenous sediments is where authigenic components (Fe/Mn micronodules, zeolites), fish debris, etc., become common (more than 10\%) in smear slides, indicating pelagic clay. Because the accumulation rates of pelagic clay and terrigenous sediments are very different, transitional deposits are exceptional.

2. Boundary of pelagic clay with siliceous biogenic sediments is the point at which there is less than $30 \%$ identifiable siliceous remains.

3. Boundary of pelagic clay with calcareous biogenic sediment is uncommon. Generally this facies passes from pelagic clay through siliceous ooze to calcareous ooze, with one important exception: At the base of many 
oceanic sections, black, brown, or red clays occur directly on basalt, overlaid by or grading up into calcareous sediments. Most of the basal clayey sediments are rich in iron, manganese, and other metallic trace elements. For proper identification they require more elaborate geochemical work than is available on board. These sediments are placed in the "Special Rock" category, and care is taken to distinguish them from ordinary pelagic clay.

\section{Siliceous Biogenic Sediment}

Siliceous biogenic sediments are distinguished from pelagic clay because they contain common siliceous microfossils. Siliceous biogenic sediments are distinguished from a calcareous category by a calcium carbonate content of less than $30 \%$.

There are two categories of siliceous biogenic sediments: (1) pelagic siliceous biogenic sediments, which contain greater than $70 \%$ siliceous microfossils and less than $30 \%$ silt and clay, and (2)transitional siliceous biogenic sediments, which contain between 10 and $70 \%$ siliceous microfossils and greater than $30 \%$ silt and clay. Soft pelagic siliceous biogenic sediments are termed siliceous oozes (radiolarian ooze or diatom ooze, depending on the dominant fossil component). Hard pelagic siliceous biogenic sediments include radiolarite, porcellanite, diatomite, and chert. Soft transitional siliceous biogenic sediments with less than $50 \%$ siliceous microfossils were termed siliceous (or diatomaceous, if diatoms were the dominant fossil component) clays or silty siliceous (diatomaceous) clays by the Leg 86 scientific party. Soft transitional siliceous biogenic sediments with greater than $50 \%$ siliceous microfossils were termed clayey diatom ooze. The standard DSDP classification scheme terms these transitional siliceous biogenic sediments siliceous muds and muddy diatom oozes, respectively, but the Leg 86 scientific party preferred to avoid use of the term mud in their sediment classification.

\section{Calcareous Biogenic Sediment}

Calcareous biogenic sediment is distinguished by a biogenic $\mathrm{CaCO}_{3}$ content in excess of $30 \%$. There are two classes: (1) pelagic calcareous biogenic sediments which contain 60 to $100 \%$ biogenic $\mathrm{CaCO}_{3}$ (less than $30 \%$ silt and clay) and (2) transitional calcareous biogenic sediments which contain 30 to $60 \% \mathrm{CaCO}_{3}$ (greater than $30 \%$ silt and clay). Only pelagic biogenic calcareous sediments were recovered on Leg 86 (Sites 576 and 577). These sediments were soft sediments and are therefore termed calcareous oozes (nannofossil or foraminiferal oozes, depending on the dominant fossil component).

\section{Terrigenous Sediments}

Terrigenous sediments are distinguished by a terrigenous component in excess of $30 \%$ and by siliceous and authigenic components each less than $10 \%$. Sediments in this category are subdivided into textural groups by smear slide estimation of the relative proportions of sand, silt, and clay. The size limits are those defined by Wentworth (1922) (Fig. 7). Five major textural groups were

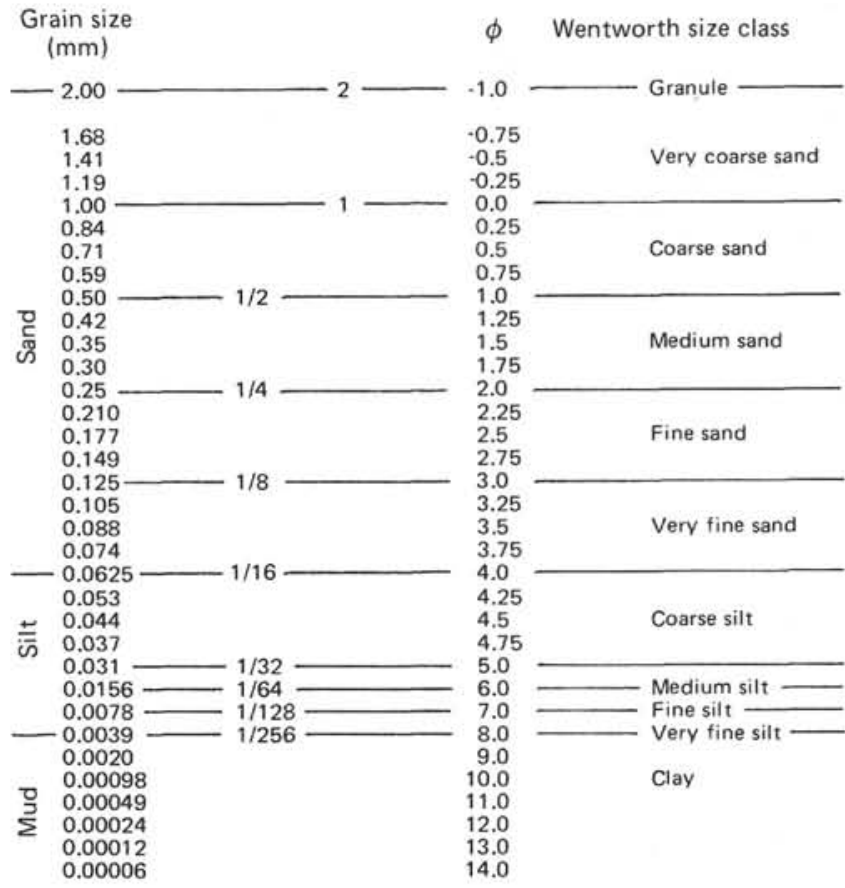

Figure 7. Grade scales for terrigenous sediments (from Wentworth, 1922).

recognized by the Leg 86 scientific party and are shown in a triangular diagram (Fig. 8). These groups are defined according to the abundance of clay $(>90 \%, 90-$ $10 \%,<10 \%)$ and the ratio of sand to silt $(>1$ or $<1)$. The term mud was not favored by the Leg 86 party; the terms silty clay and sandy clay were used instead.

\section{Volcanogenic Sediments}

Pyroclastic rocks are described according to the textural and compositional scheme of Wentworth and Williams (1932). The textural groups are (1) volcanic breccia: more than $32 \mathrm{~mm}$ in size; (2) volcanic lapilli: between 4 and $32 \mathrm{~mm}$ in size; and (3) volcanic ash: less than $4 \mathrm{~mm}$ in size (tuff when indurated). The composition of these pyroclastic rocks is described as vitric

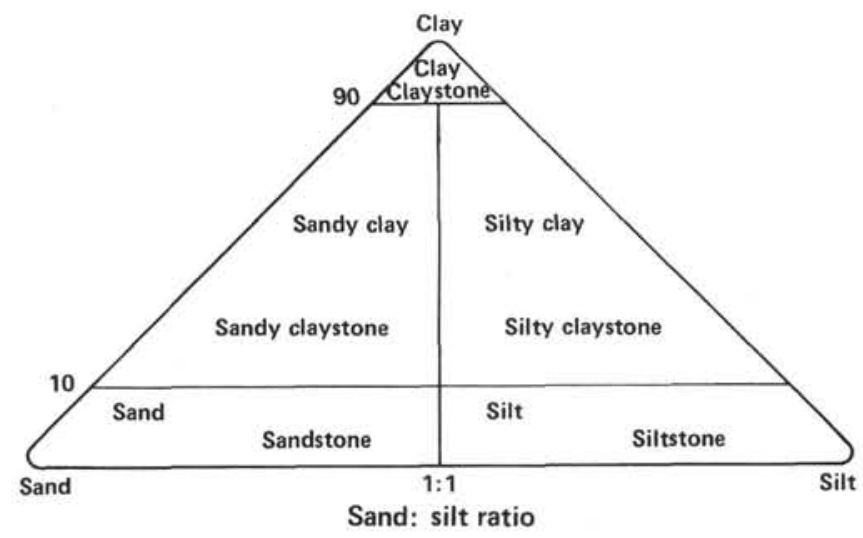

Figure 8. Triangular diagram showing classification scheme for terrigenous sediments used on DSDP Leg 86. 
(glass), crystalline, or lithic. Volcanic ash layers were recovered at all sites drilled on Leg 86 ; no volcanic breccia or lapilli layers were encountered.

\section{Special Rock Types}

The definition and nomenclature of sediment and rock types not included in the system described above are left to the discretion of shipboard scientists, with the recommendation that they adhere as closely as practical to conventional terminology. In this category fall such rocks as intrusive and extrusive igneous rocks, evaporites, shallow water limestones, dolomites, gravels, conglomerates, breccias, metalliferous brown clays, and concretions. Special rock types encountered by the Leg 86 scientific party included manganese nodules and basalts.

\section{Basement Description Conventions}

\section{Core Handling}

Basalt basement rocks were recovered only in Core 19 of Hole 581 on Leg 86. These basalts were split using a rock saw with a diamond blade into "archive" and "work" halves. Styrofoam spacers were taped between basalt pieces inside the liner, and each piece was numbered sequentially from the top of each section, beginning with the number 1 . Pieces were labeled on the rounded, not the sawed, surface. Pieces that could be fitted together before splitting were given the same number, but were consecutively lettered $1 \mathrm{~A}, 1 \mathrm{~B}, 1 \mathrm{C}$, etc. Spacers were placed between pieces with different numbers, but not between those with different letters and the same number.

All pieces that are cylindrical and longer than the liner diameter have orientation arrows pointing to the top of the section, both on archive and working halves. Special procedures were used to ensure that orientation was preserved through every step of the sawing and labeling process. Since the pieces are rotated during drilling, it is not possible to sample for declination studies.

Additional Site 581 basalts were recovered during Leg 88 at Holes 581A, 581B, and 581C. Description and sampling of all of the Site 581 basalts was deferred until after Leg 88. Detailed descriptions and results of shorebased studies of these basalts are presented in the Leg 88 Initial Reports volume (Duennebier, Stephen, et al., in press).

\section{Igneous Rock Classification}

Classification of basalts is based mainly on mineralogy and texture. Thin-section work in general adds little new information to the hand-specimen classification.

Basalts are termed aphyric, sparsely phyric, moderately phyric, or phyric, depending on the proportion of phenocrysts visible with the binocular microscope (about $\times 12$ ). Basalts are called aphyric if phenocrysts are absent. For practical purposes, this means that if one piece of basalt is found with a phenocryst or two in a section where all other pieces lack phenocrysts, and no other criteria such as grain size or texture distinguish this basalt from the others, then it is described as aphyric. A note of the rare phenocrysts is included in the general description, however. This approach enables us to restrict the number of lithologic units to those with clearly distinctive and persistent visible differences.

Sparsely phyric basalts are those with 1 to $2 \%$ phenocrysts in almost every piece of a given core or section. Clearly contiguous pieces without phenocrysts are included in this category and the lack of phenocrysts is again noted in the general description.

Moderately phyric basalts contain 2 to $10 \%$ phenocrysts. Aphyric basalts within a group of moderately phyric basalts are separately termed aphyric basalts.

Phyric basalts contain more than $10 \%$ phenocrysts. No separate designation is made for basalts with more than $20 \%$ phenocrysts; the proportion indicated in the core forms should be sufficient to guide the reader.

The basalts are further classified by phenocryst type, and a modifying term precedes the terms phyric, sparsely phyric, etc. For example, a plagioclase-olivine moderately phyric basalt contains 2 to $10 \%$ phenocrysts, most of them plagioclase, but with some olivine.

\section{Biostratigraphy, Paleomagnetics, and Basis for Age Determination}

Microfossil zonations of sediments cored on Leg 86 were based on the scheme outlined in Figure 9. The foraminifera zonation was based on Blow (1969), Stainforth et al. (1975) as modified and correlated by Berrgren, Kent, and Flynn (in press), and Pessagno (1967). The nannofossil zonation was constructed from Martini (1971), Bukry (1973, 1981), van Hinte (1976), Verbeek (1977), Roth (1978), Okada and Bukry (1980), and S. Monechi and H. Thierstein (pers. comm., 1984). The radiolarian zonation was constructed from Hays (1970), Foreman (1975), and Riedel and Sanfilippo (1970, 1971, 1978). The diatom zonation was modified from Burckle (1972), Koizumi (1973, 1975), Burckle and Opdyke (1977), and Barron (1980), as shown in Koizumi and Tanimura (this volume). The pelagic clay intervals recovered at Sites 576,578 , and 581 were dated by ichthyoliths (Doyle, this volume).

The geomagnetic time scale is from Berggren, Kent, and Flynn (in press). The numbering schemes are based on LaBrecque et al. (1977) for numbering marine magnetic anomalies, on Theyer and Hammond (1974) and Opdyke et al. (1974) for geomagnetic epochs, and on Tauxe et al. (1984) for geomagnetic chrons. All age boundaries except the Miocene/Pliocene agree with those given by Palmer (1983). The Leg 86 shipboard party uses an age of $5.1 \mathrm{~m}$.y. for the Miocene/Pliocene boundary in the site chapters (this volume), whereas Palmer (1983) places an age of $5.3 \mathrm{~m} . \mathrm{y}$. on this boundary.

Downhole sedimentation rates were calculated on board ship from biostratigraphic and paleomagnetic results and are presented in the site chapters.

The following letters are used on core description forms to indicate fossil abundance:
$\mathrm{A}=$ abundant (many species and specimens),
$\mathrm{C}=$ common (many species, easy to make age as- signment),
$\mathrm{R}=$ rare (enough for age assignment), and
$\mathrm{B}=$ barren. 
Letters used to designate fossil preservation are

$\mathrm{E}=$ excellent (no dissolution or abrasion),

$\mathrm{G}=$ good (very little dissolution or abrasion),

$\mathrm{M}=$ moderate (dissolution and/or abrasion and/or recrystallization very noticeable), and

$\mathrm{P}=$ poor (substantial or very strong evidence of dissolution and/or abrasion, and/or recrystallization).

\section{Shipboard Geochemical Measurements}

\section{Carbonate Bomb}

Percent $\mathrm{CaCO}_{3}$ was determined on board ship by the carbonate bomb technique of Müller and Gastner (1971). In this simple procedure, a sample is dried in an oven, ground to powder, and treated with $\mathrm{HCl}$ in a closed cylinder. Any resulting $\mathrm{CO}_{2}$ pressure is proportional to the $\mathrm{CaCO}_{3}$ content of the sample. Application of the calibration factor to the manometer reading $(\times 100)$ yields percent $\mathrm{CaCO}_{3}$. Percent error can be as low as $1 \%$ for sediments high in $\mathrm{CaCO}_{3}$; in general an accuracy of about 2 to $5 \%$ can be obtained.

Carbonate bomb samples were run from the calcareous (turbidite) layers at Holes 576 and $576 \mathrm{~B}$, at frequent intervals throughout Holes 577 and 577A, and from the section in Hole 578, Core 20 containing silicified foraminifers. These data are presented on the core description sheets (Fig. 4). The sample interval is designated by two numbers: the section number, followed by the top of the sample interval. For example, a sample from Section 2, 11-12 cm, with $90 \%$ calcium carbonate will be represented on the core description sheet as " $2,11 \mathrm{~cm}=$ $90 \%$."

\section{Interstitial Water}

Interstitial water samples were routinely analyzed for $\mathrm{pH}$, alkalinity, salinity, calcium, magnesium, and chlorinity on board ship. One sample was analyzed from every core in Hole 576A, and from every third core at Sites 577 through 581. In addition, three in situ pore water samples from Site 576 were analyzed. Data from all these analyses are given in the site chapters (this volume). Sediments are squeezed using a stainless steel press. The water collects in plastic syringes and is then filtered through $0.45-\mu \mathrm{m}, 1$-inch millipore filters. Interstitial waters collected with the In Situ Pore Water Sampler are filtered through $0.4-\mu \mathrm{m}, 13-\mathrm{mm}$ filters prior to analysis.

$\mathrm{pH}$ is determined using a Corning Model $130 \mathrm{pH}$ meter and a Markson combination electrode. The $\mathrm{pH}$ meter is calibrated with 4.01 and 7.42 buffer standards. Readings are originally made in millivolts and are later converted to $\mathrm{pH}$. All $\mathrm{pH}$ measurements are made in conjunction with alkalinity measurements.

Alkalinity is determined potentiometrically. Five to $10 \mathrm{ml}$ samples are first tested for $\mathrm{pH}$ and then titrated with $0.1 \mathrm{~N} \mathrm{HCl}$. Near the end point, acid is added in $0.01-\mathrm{ml}$ or $0.005-\mathrm{ml}$ increments. Millivolt readings are noted for each increment. The exact end point is then calculated using the Gran Factor method (Gieskes and Rogers, 1973).
Salinity is calculated from the fluid refractive index, as measured by a Goldberg optical refractometer, using this expression:

$$
\text { Salinity }(\%)=0.55 \times \Delta N \text {, }
$$

where $\Delta N$ is the refractive index multiplied by $10^{4}$. The refractometer's calibration is checked periodically using a IAPSO seawater standard and deionized water.

Calcium is determined by titrating a $0.5-\mathrm{ml}$ sample with EGTA (a complexing agent) using GHA as an indicator. To sharpen the end point, the calcium-GHA complex is extracted into a layer of butanol. No correction is made for strontium, which is also included in the result.

Magnesium is determined by titrating a buffered 0.5 $\mathrm{ml}$ sample to an Ereochrome Black-T end point using EDTA (sodium salt) as a titrant. This method analyzes all alkaline earths, including calcium, magnesium, strontium, and magnesium; concentrations are obtained by subtracting the calcium (which includes strontium) from this analysis.

Chlorinity is determined by titrating a $0.1-\mathrm{ml}$ sample diluted with $1 \mathrm{ml}$ deionized water with silver nitrate to a potassium chromate end point.

Methods and equipment are checked and standardized at each site using IAPSO standard seawater. As a further check, a surface seawater sample is also analyzed and archived. This sample is also used to test for possible drill water contamination of the interstitial water samples.

\section{Physical Properties Procedures}

Physical properties measured on board the Glomar Challenger during Leg 86 included the following: (1) saturated bulk density measured with a Gamma Ray Attenuation and Porosity Evaluator (GRAPE), (2) saturated bulk density and water content using gravimetric analyses, (3) compressional wave velocity, using the Hamilton Frame, (4) shear wave velocities, using specially built transducers, and (5) shear strength values, using both a mechanical and a hand-held device.

Physical properties measurements were generally all made within a $30-\mathrm{cm}$ length of a section that appeared to be undisturbed. Occasional measurements were taken in obviously disturbed regions to examine the effects of disturbance. The frequency of measured intervals varied greatly from approximately one per section at Site $\mathbf{5 7 6}$ to one per core at Site 581. Measurements were made more frequently around lithologic boundaries.

Most of the methods and techniques used to assess the physical properties on Leg 86 are discussed in detail by Boyce $(1976,1977)$. Consequently, only a brief review of the methods is given here.

\section{GRAPE}

The Gamma Ray Attenuation and Porosity Evaluator (GRAPE) was used to assess the saturated bulk density of sediments from all the sites drilled during Leg 86 . GRAPE analysis compares the attenuation of gamma rays through a sediment sample of unknown bulk densi- 


\section{A. A. WRIGHT}

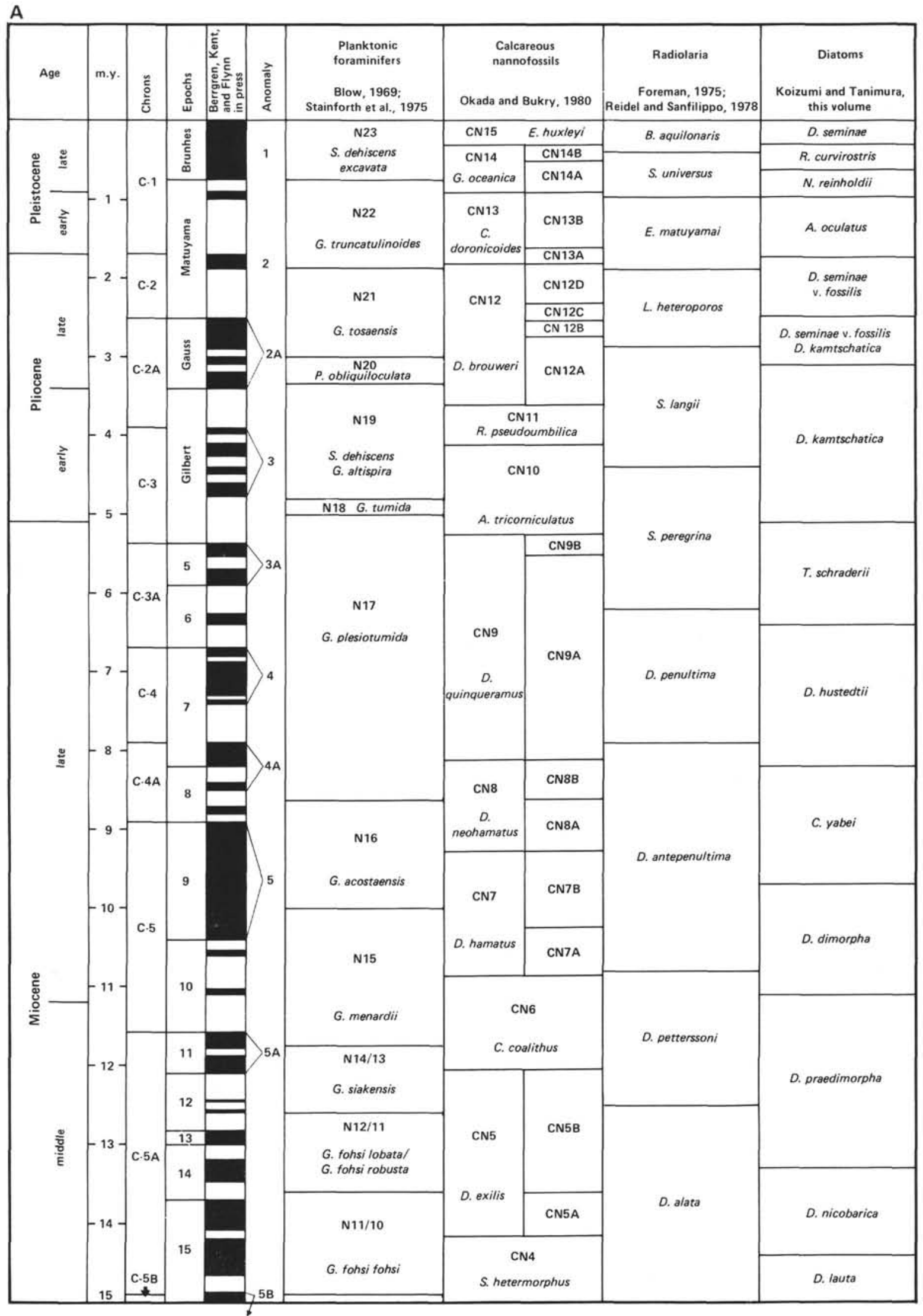

Figure 9. Biostratigraphic zonations for microfossil groups used to date Leg 86 cores. A. Recent through middle Miocene zonations. B. Middle Miocene through Cretaceous zonations. The tie to the paleomagnetics is, in part, by second-order correlation. 
B

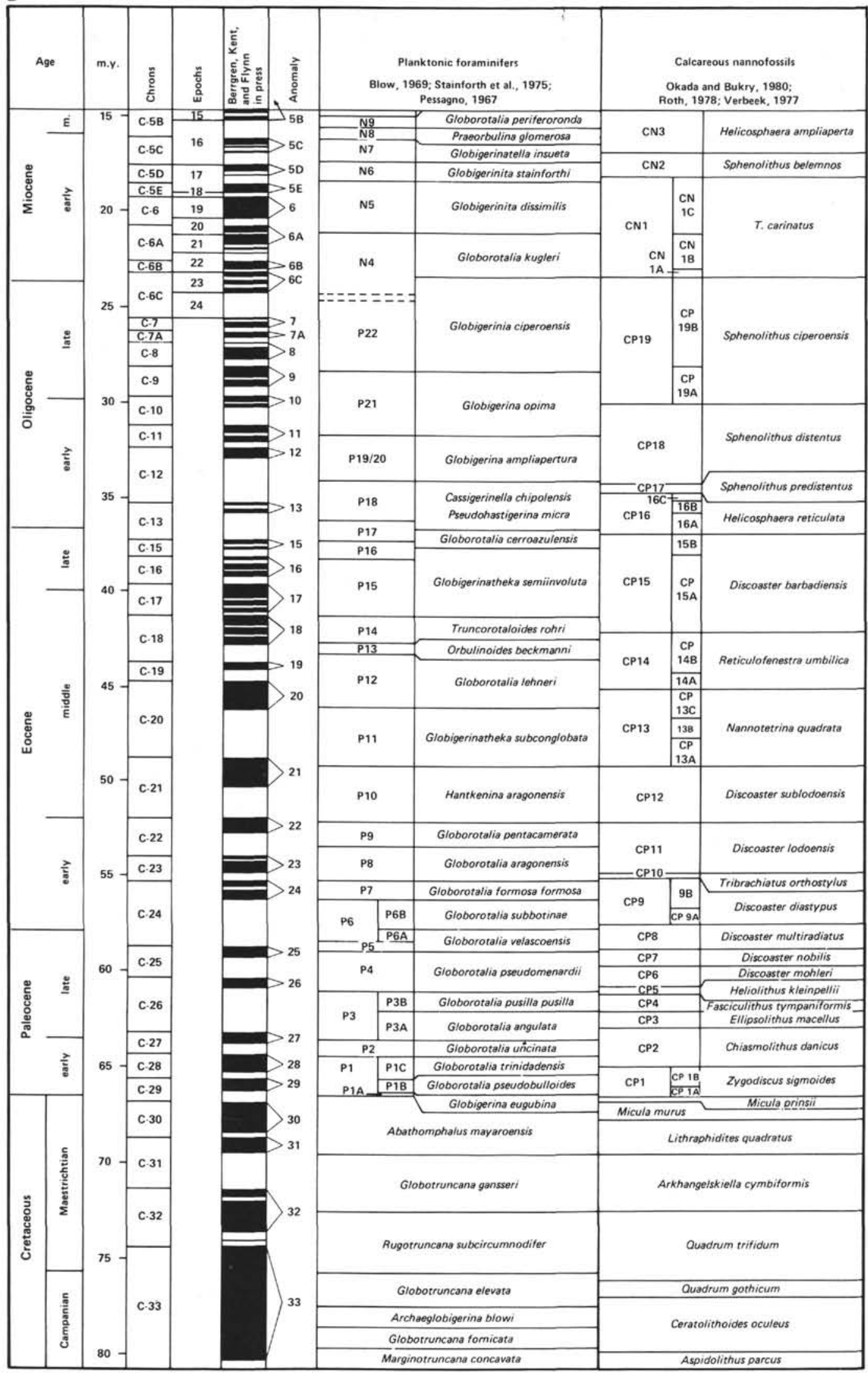

Figure 9. (Continued). 
ty with that of a reference sample of known density. The main problem with assessing density from gamma ray attenuation measurements is that attenuation coefficients vary for different mineral types.

Two GRAPE techniques were employed: (1) continuous GRAPE in which the entire, unsplit 1.5 -m sections were scanned providing a continuous analog record of approximate bulk density, and (2) 2-min. GRAPE, in which the gamma count was measured through a sediment sample contained in a 1-inch high, 1-inch diameter stainless steel cylinder capped by plexiglass end caps. The longer count times over an accurately known sediment thickness provide more reliable gamma counts. The calibration and calculation procedures are given in Boyce (1976). The 2-min. GRAPE samples were later used as samples for shipboard gravimetric analyses.

\section{Gravimetric Measurements}

Two samples were taken adjacent to each other using the 1-inch high, 1-inch diameter stainless steel cylinders. One sample was subjected to the 2-min. GRAPE test before being weighed, dried at $105^{\circ} \mathrm{C}$, and then reweighed. The second sample was packed and returned to a shorebased laboratory as a check on the shipboard measurements. The metal cylinders (referred to sometimes as "Boyce cylinders") were inserted into the split section. To minimize the disturbance caused by this insertion, a 20-25 V dc voltage was applied between the cylinder (cathode) and a nearby platinum anode (placed in the sediment). The ease of insertion and subsequent lack of disturbance results from the electro-osmotic effect which continuously lubricates the steel cathode with water, preventing the sediment from sticking to the cylinder. From the wet and dry weights of the sediment sample and the volume of the sample, the bulk density, water content, porosity, and void ratio were calculated. Salt corrections were made assuming $35 \%$ salinity and a water density of $1.024 \mathrm{~g} / \mathrm{cm}^{3}$.

\section{Velocity Measurements}

Compressional wave velocities were measured at 400 $\mathrm{kHz}$ using the Hamilton Frame Velocimeter. The apparatus was calibrated using various standards, including distilled water. It was found for nearly all the cores taken on Leg 86 that it was appropriate to measure the velocity on the split core through the liner. This proved very accurate because the HPC cores filled the liners so no errors were introduced by uncertain sediment thicknesses. Velocities were measured immediately after the core had been split longitudinally, which was at least 4 hr. after recovery. This time period was to allow the core temperature to reach that of the laboratory. Temperature was measured at the same time the velocity measurement was made, and all reported velocities are corrected to $20^{\circ} \mathrm{C}$ using standard seawater velocity/temperature tables. It was found that a resolution of less than 2 $\mathrm{m} / \mathrm{s}$ was possible when carefully calibrated.

Shear wave velocities were measured by timing a shear wave pulse between two specially designed transducers that were pushed into the split section. The technique employed piezoelectric bender elements; the transmitter was driven with the rising edge of a $10-\mathrm{V}$ square wave, while the received signal was high-pass filtered to remove extraneous noise. Shear wave velocity measurements are not normally performed on DSDP cores, and the reader is referred to Schultheiss (this volume) for more details.

\section{Shear Strength Measurements}

Vane shear strengths were measured at all sites on Leg 86 using the modified Wykeham-Farrance Vane Shear Apparatus. The theory and operation of this device is described by Boyce (1976). A four-blade vane is inserted into the split section and a motor rotates it via a torsion spring. The sediment cylindrically shears around the vane. The shear strength is given as a function of the vane size, the spring stiffness, and the amount of torque at failure.

A Torvane hand-held device was also used. This operates on the same principle as the Wykeham-Farrance device, except the test is not as well controlled. However, it is a very quick test to perform and it was interesting to compare the data from the two devices.

\section{Heat Flow}

A new heat flow instrument, developed by R.P. von Herzen and others at WHOI, was used for the first time to record bottom hole temperatures. The instrument is specifically designed for use in a modified HPC nose cone. It consists of a temperature sensor (thermistor), a recorder, and batteries that are inserted as a unit into a slot opening in the metal wall of the HPC nose cone shoe so that the temperature sensor is placed close to the shoe's tip. The recorder is a minicomputer, energized by the batteries, that stores data of measured temperatures as a function of time at intervals specified by a program that is loaded into the computer prior to operation. Because of the short time constant of the instrument (10-s intervals), a recording time of $5 \mathrm{~min}$. appears to be sufficient for estimating the undisturbed temperature of the sediment by extrapolation of the cooling curve. This instrument thus provides an efficient way of measuring undisturbed sediment temperature without interfering with the coring process. Heat flow measurements were made at all Leg 86 sites except Site 581 (Horai and von Herzen, this volume).

\section{Photography}

Black and white photos of all cores collected during Leg 86 are printed in the site chapters (this volume). In addition, both color core slides and black and white closeups are archived at DSDP and are available for consultation.

\section{Obtaining Samples}

Potential investigators who wish to obtain samples should refer to the NSF Sample Distribution Policy for DSDP and ODP. Sample request forms may be obtained from the Curator, Ocean Drilling Program, Texas A\&M University, College Station, Texas 77843. Requests must 
be as specific as possible: include site, hole, core, section, interval within a section, and volume of sample required.

\section{REFERENCES}

Barron, J. A., 1980. Lower Miocene to Quaternary diatom biostratigraphy of Leg 57, off northeastern Japan, Deep Sea Drilling Project. In Scientific Party, Init. Repts. DSDP, 56, 57, Pt. 2: Washington (U.S. Govt. Printing Office), 641-686.

Berggren, W. A., Kent, D. V., and Flynn, J. J., in press. Paleogene geochronology and chronostratigraphy. In Snelling, N. J. (Ed.), Geochronology and the Geological Record. Geol. Soc. London Spec. Pap.

Blow W. H., 1969. Late middle Eocene to Recent planktonic foraminiferal biostratigraphy. In Bronnimann, P., and Renz, H. H., (Eds.), Proc. Int. Conf. Planktonic Microfossils, Ist, Leiden (Brill), 6: 199-421.

Boyce, R. E., 1976. Definitions and laboratory techniques of compressional sound velocity parameters and wet-water content, wet bulk density, and porosity parameters by gravimetric and gamma ray attenuation techniques. In Schlanger, S. O., Jackson, E. D., et al., Init. Repts. DSDP, 33: Washington (U.S. Govt. Printing Office), 931-958.

1977. Deep Sea Drilling Project procedures for shear strength measurement of clayey sediment using modified Wykeham Farrance Laboratory Vane Apparatus. In Barker, P. F., Dalziel, I. W. D., et al., Init. Repts. DSDP, 36: Washington (U.S. Govt. Printing Office), 1059-1068.

Bukry, D., 1973. Low-latitude coccolith biostratigraphic zonation. In Edgar, N. T., Saunders, J. B., et al., Init. Repts. DSDP, 15: Washington (U.S. Govt. Printing Office), 685-704.

1981. Cenozoic coccoliths from the DSDP. The Deep Sea Drilling Project: A Decade of Progress. Soc. Econ. Paleontol. Mineral. Spec. Publ., 32:335-353.

Burckle, L., 1972. Late Cenozoic planktonic diatom zones from the eastern equatorial Pacific. Nova Hedwigia Beih., 39:217-246.

Burckle, L., and Opdyke, N. D., 1977. Late Neogene diatom correlations in the Circum-Pacific. Proc. Int. Congr. Pacific Neogene Stratigraphy, 1st, Tokyo (Kaiyo Shuppan), pp. 255-284.

Duennebier, R. K., Stephen, R. A., et al., in press. Init. Repts. DSDP, 88: Washington (U.S. Govt. Printing Office).

Foreman, H. P., 1975. Radiolaria from the North Pacific, Deep Sea Drilling Project, Leg 32. In Larson, R. L., Moberly, R., et al., Init. Repts. DSDP, 32: Washington (U.S. Govt. Printing Office), 579-676.

Gealy, E. L., Winterer, E. L., and Moberly, R. M., Jr., 1971. Methods, conventions, and general observations. In Winterer, E. L., Riedel, W. R., et al., Init. Repts. DSDP 7, Pt. 1: Washington (U.S. Govt. Printing Office), 9-26.

Gieskes, J. M., and Rogers, W. C., 1973. Alkalinity determination in interstitial waters of marine sediments. J. Sediment. Petrol., 43: 272-277.

Hays, J. D., 1970. Stratigraphy and evolutionary trends of Radiolaria in North Pacific deep-sea sediments. In Hays, J. D. (Ed.), Geological Investigations of the North Pacific. Mem. Geol. Soc. Am. 126: 185-218.

Heath, G. R., Burckle, L. H., Wright, A. A., Bleil, U., D'Agostino, A., et al., 1982. Glomar Challenger at the Cretaceous-Tertiary boundary. Nature (London), 299:208.

Heezen, B. C., Fischer, A. G., Boyce, R. E., Bukry, D., Douglas, R. G., et al., 1971. Site 47. In Fischer, A. G., Heezen, B. C., et al., Init. Repts. DSDP, 6: Washington (U.S. Govt. Printing Office), 67-143.

Kennett, J., von der Borch, C., et al., in press. Init. Repts. DSDP, 90: Washington (U.S. Govt. Printing Office).

Koizumi, I., 1973. The Late Cenozoic diatoms of Sites 183-193, Leg 19, Deep Sea Drilling Project. In Creager, J. S., Scholl, D. W., et al., Init. Repts. DSDP, 19: Washington (U.S. Govt. Printing Office), 805-856.

1975. Neogene diatoms from the western margin of the Pacific Ocean, Leg 31, Deep Sea Drilling Project. In Karig, D. E., In- gle, J. C., Jr., et al., Init. Repts. DSDP, 31: Washington (U.S. Govt. Printing Office), 779-819.

LaBrecque, J. L., Kent, D. V., and Cande, S. C., 1977. Revised magnetic polarity time scale for Late Cretaceous and Cenozoic time. Geology, 5:330-335.

Martini, E., 1971. Standard Tertiary and Quaternary calcareous nannoplankton zonation. Plankt. Conf., Roma, 2nd, pp. 739-785.

Matthews, D. J., 1939. Tables of the Velocity of Sound in Pore Water and in Seawater. London: Admiralty (Hydrographic Department).

Müller, G., and Gastner, M., 1971. The "Karbonat Bombe", a simple device for the determination of the carbonate content in sediments, soils and other materials. Neues. Jahrb. Mineral. Monatsh., 10: 466-469.

Okada, K., and Bukry, D., 1980. Supplementary modification and introduction of code numbers to the low-latitude coccolith biostratigraphic zonation (Bukry, 1973, 1975). Mar. Micropaleontol. 5: 321-325.

Opdyke, N. D., Burckle, L. H., and Todd, A., 1974. The extension of the magnetic time scale in sediments of the central Pacific Ocean. Earth Planet. Sci. Lett., 22:300-306.

Palmer, A. R., 1983. The decade of North American Geology 1983 geological time scale. Geology, 11(9):503-504.

Pessagno, E. A., 1967. Cenomanian-Turonian stratigraphy in the western Gulf coastal plain area. In Brönniman, P., and Ranzrenz, H. H. (Eds.), Proc. Int. Conf. Planktonic Microforaminifera, 1st, 2: 509-525.

Prell, W. L., Gardner, J. V., and Shipboard Scientific Party, 1982. Leg 68: Introduction, explanatory notes, and conventions. In Prell, W. L., Gardner, J. V., et al., Init. Repts. DSDP, 68: Washington (U.S. Govt. Printing Office), 5-13.

Riedel, W. R., and Sanfilippo, A., 1970. Radiolaria, Leg 4, Deep Sea Drilling Project. In Bader, R. G., Gerard, R. D., et al., Init. Repts. $D S D P, 4$ : Washington (U.S. Govt. Printing Office), 503-575. 1971. Cenozoic Radiolaria from the western tropical Pacific, Leg 7. In Winterer, E. L., Riedel, W. R., et al., Init. Repts. $D S D P, 7$, Pt. 2: Washington (U.S. Govt. Printing Office), $1529-1672$.

1978. Stratigraphy and evolution of tropical Cenozoic radiolarians. Micropaleontology, 24:61-96.

Roth, P. R., 1978. Cretaceous nannoplankton biostratigraphy and oceanography of the northwestern Atlantic Ocean. In Benson, W. E., Sheridan, R. E., et al., Init. Repts. DSDP, 44: Washington (U.S. Govt. Printing Office),731-759.

Staff Scientific Party, 1982. On Leg 86, Challenger investigates NW Pacific. Geotimes, 27(11):20-22.

Stainforth, R. M., Lamb, J. L., Luterbacher, H., Beard, J. H., and Jeffords, R. M., 1975. Cenozoic planktonic foraminiferal zonations and characteristics of index forms. Univ. Kans. Paleontol. Contrib. Pap. 62:1-425.

Tauxe, L., Tucker, P., Petersen, N. P., and LaBrecque, J. L., 1984. Magnetostratigraphy of Leg 73 sediments. In Hsü, K. J., LaBrecque, J. L., et al., Init. Repts. DSDP, 73: Washington (U.S. Govt. Printing Office), 609-621.

Theyer, F., and Hammond, S. R., 1974. Cenozoic magnetic time scale in deep-sea cores: completion of the Neogene. Geology, 2: 487-492.

van Hinte, J. E., 1976. Cretaceous time scale. Am. Assoc. Pet. Geol. Bull., 60(4):269-287.

Verbeek, J. W., 1977. Calcareous nannoplankton biostratigraphy of middle and upper Cretaceous deposits in Tunisia, southern Spain and France. Utrecht Micropaleont. Bull., 16:1-157.

Wentworth, C. K., 1922. A scale of grade and class terms of clastic sediments. J. Geol., 30:377-390.

Wentworth, C. K., and Williams, H., 1932. The classification and terminology of the pyroclastic rocks. Rep. Comm. Sedimentation, Bull. Nat Res. Council, U.S., 80:10-53.

Date of Initial Receipt: 18 December 1983

Date of Acceptance: 10 August 1984 